Interim Government or the ECOMOG forces of relief shipments coming into the country is a reasonable requirement, in our view.

4) Now that the Interim Government is in residence within the country, the US, after extending recognition, should resume its economic and emergency assistance to that country, working through the Interim Government. Further, working through the Interim Government, the US should unblock all non-lethal assistance provided for Liberia under any of the pending or previous authorizations of assistance, and, in fact, should expand its assistance program to help meet the acute needs for food and health relief, resettlement of refugees and displaced persons, and restoration of basic services.

5) The US should assist in the immediate evacuation of refugees from Monrovia and elsewhere. There is especially a need to provide security and safe passage for the thousands of persons at the Presidential Palace, many of whom come from the former President's region or were associated with his regime and now fear for their lives. Safe passage and refugee camp arrangements would be needed until these people can safely return to their homes.

Liberia is too close and important a friend of the US, and has suffered too much already, in which suffering we are complicit, to merit being ignored or manipulated by our government in a period of such acute need and such promise for renewal.

To continue to hesitate in supporting the Interim Government headed by Dr. Sawyer, and to continue to encourage fighting forces to believe that some better arrangement than the Interim Government offers might come to them through US influence, as we believe that some US officials have done, only prolongs the suffering of the Liberian people, and impedes real progress toward full democratic and constitutional government in that country.

We hope that you will give your most conscientious attention to the points we raise, and take appropriate action.

Pearl T. Robinson

TransAfrica, Boston Chapter

\title{
In Memoriam: Gwendolen Carter
}

Gwendolen M. Carter died in Orange City, Florida, on 20 February 1991. Her life spanned the extraordinary events and transformations of the twentieth century, and she was an active observer and participant in many of them. She reached out to people, and they, in turn, saw in her someone who would champion their causes and respond to their needs. Human beings rather than detached institutions or political structures were at the center of her political analyses. Her particular concern with Africa, and her in-depth involvement with South Africa, drew her into dramatic circumstances. She discussed politics with Kwame Nkrumah and saluted Nelson Mandela as he was led out of the courtroom to life imprisonment.

Gwen Carter was born in Hamilton, Ontario, and received the BA from the University of Toronto in 1929. She then went to Oxford University where she also received the BA in 1931. She was a member of the faculty of McMaster University at Hamilton, Ontario, from 1932 to 1935 before returning to Oxford to complete the MA degree in 1936. In 1938 she was awarded the PhD from Radcliffe College of Harvard University. She taught at Wellesley College from 1938 to 1941 and at Tufts College in 1942-43, before joining the faculty at Smith College where she remained from 1943 to 1964 and where she was named to the Sophia Smith Chair of Political Science in 1961.

In 1964 she was invited to become the director of the African Studies Program at Northwestern University and was appointed the Melville J. Herskovits Professor of African Affairs. In 1974 she agreed to join the faculty of the African Studies Program and the Political Science Department of Indiana University, and for the next ten years she enlivened the intellectual life of her colleagues and students. In 1984 she accepted an offer from the University of Florida, where she taught until 1987. Her international stature was recognized by the conferral of honorary degrees from 13 universities in the United States and Canada, the George V Medal for Public
Service in 1935, the Achievement Award of the American Association of University Women in 1962, and the Distinguished Scholar Award of the ASA in 1978. She was president of the African Studies Association in 195859, president of the New England Political Science Association in 1959-60 and vice president of the American Political Science Association in 196364. In the 1940s she became an American citizen and was frequently called upon as a consultant by government agencies and private organizations. She was a member of the board of the African-American Institute for more than 20 years.

Gwen Carter continued to publish and to be professionally engaged into her 80s. Her publications, which spanned a period of more than 40 years, are her enduring and impressive legacy to all of us as well as to future generations of scholars. Her work ranged from her first book in 1947 on the British Commonwealth to numerous other books, articles and essays. The Governments of Great Britain, France, and the Soviet Union, 
which she coauthored with John $\mathrm{H}$. Rainey in 1949, was followed by five editions with John Herz. For many years this was the preeminent text in comparative politics in departments of political science throughout the United States. In the Preface to the first edition, Carter and Rainey summed up their perspective. Their approach aimed "to depict governments as a living complex of activities and arrangements which change and develop in response to the character, needs, desires, and purposes of human beings." Gwen's concern with political power and its effects on people's lives led her to an extensive stay in South Africa in the 1950s and resulted in her pioneering study, The Politics of Inequality: South Africa Since 1948. Some of her comments in the Introduction to the book epitomize Gwen's academic beliefs and commitment. "[T]hroughout most of my two substantial periods of investigation in [South Africa] I was far more concerned with understanding the points of view and character of action of the different groups in the community than judging them. No one who goes to South Africa for a serious study of the situation can ultimately avoid judgements. But to the best of my ability I have tried to separate facts and analysis from such judgements, and to let the former speak for themselves." On trips to South Africa Gwen met and interacted with political and intellectual leaders at every level. She made lifelong friends throughout the country and became a symbol of a caring outside world. This was the crucial period of the implementation of apartheid and Gwen's insights provided scholars and policymakers with an understanding of what was happening in South Africa.

Her monumental work, From Protest to Challenge: A Documentary History of African Politics in South Africa, 1882-1964, which was edited with Thomas Karis, Sheridan Johns and Gail Gerhart, is a collection of annotated documents and essays chroni- cling African nationalism in South Africa and the struggle for political, social and economic rights. Without Gwen's efforts to collect, preserve and protect these documents many of them would certainly have been lost. In particular, she helped arrange for important materials, which might have been confiscated by the authorities, to leave South Africa.

So far I have written about Gwendolen Carter the scholar, the consummate professional and the international figure. On a more personal level, she was a woman of great courage and independence who refused to accept barriers of any sort. Despite the limitations imposed on her by a severe case of polio when she was four years old, she was never spatially nor intellectually confined. In reminiscing, Gwen always said, "I was more interested in what I could do than I was interested in what I couldn't do." Her father, a pediatrician, and her mother encouraged her to do anything that she could do. No part of Africa, or for that matter, of the world, was inaccessible despite her physical disability. In an era of male domination, Gwen considered no academic position or office beyond her reach. Her curiosity, interest in human beings, refusal to accept barriers of any sort and her sense of adventure are all legendary. Gwen loved to travel, but she never went simply as a tourist. She was purposeful and set out to find out what was going on and "to meet everyone." In fact this started early. At the age of 19 , on a visit to her uncle who was mayor of Oxford at the time, she was asked to act as mayoress for a day, and she was presented to the Prince of Wales. She really enjoyed meeting new people; she kept the contacts alive through her voluminous correspondence, and on her return visits she almost seemed a member of the family. Through her conversations and questioning she gained insights and understanding, and she translated these impressions into her writings.

As a young woman, she traveled to Nazi Germany with her lifelong friend
Louise Holborn. In 1948-49 she went on a round-the-world trip visiting Commonwealth countries including South Africa where she remained for three months, driving herself in a specially adapted car as she criss-crossed the country. In the 1950s, on the eve of independence for many African countries, she again traveled extensively on the continent. Her detailed accounts of her meetings and impressions will some day prove to be an invaluable source of information for researchers on this crucial period in African history.

Gwen was a great teacher. She shared her knowledge fully with her students, and she generously opened her home to them for meals, seminars and receptions. But she also had high academic standards, and if these were not met she had no hesitation in letting students know where they stood. She helped countless students from Africa adjust to the demands of life in the United States and in many instances was responsible for their coming to America. A number of her students are now at universities or in government positions in Africa.

It has been a great privilege for me to know Gwen Carter and to work with her on several projects. Gwen's sense of freshness and excitement nurtured and sustained ideas. Occasionally we had different opinions, but we always discussed them fully and resolved them through ongoing and lively debate. She was a woman of deep convictions and real courage. I can still hear her voice on her return from South Africa at the age of 80 after she had been held in detention and interrogated by South African police: "I simply refused to talk with them. I just kept demanding to see the American ambassador."

I honor Gwen Carter as a teacher, a researcher, a personal friend and a pioneer. She was a woman of fearless integrity and intrepid mind.

Patrick O'Meara African Studies Program Indiana University 